\title{
Defining the Law of Nations: the École romande du droit naturel and the Lausanne Edition of Grotius' De jure belli ac pacis (1751-1752)
}

\author{
Simone Zurbuchen
}

The single most important Swiss contribution to the law of nations in the eighteenth century is Emer de Vattel's treatise Le Droit des Gens, ou Principes de la Loi Naturelle, appliqués à la Conduite \& aux Affaires des Nations \& des Souverains (1758). ${ }^{1}$ Unlike Jean Barbeyrac and Jean-Jacques Burlamaqui, whose reputation as outstanding natural law scholars is to a lesser or greater extent linked with their being teachers of natural law at the Protestant academies of Lausanne and Geneva, Vattel remained for most of his life an independent scholar and towards the end of his life became the chief advisor to the government of Saxony on foreign affairs. Had Frederick II of Prussia been willing to keep his father's promise to found an academy in Neuchâtel, Vattel might well have become a teacher of the law of nature and nations in his native principality, and thereby resumed the project of lecturing on natural law conceived by Louis Bourguet, who from 1731 to 1742 held the chair of philosophy and mathematics sponsored by the town of Neuchâtel and the guilds, and who also lectured on natural law. ${ }^{2}$

As a classic in the field, Vattel's treatise is well known, and scholars are aware that his main reference was Christian Wolff, whose theory of the law of

1 Emer de Vattel, Le Droit des Gens, ou Principes de la Loi Naturelle, appliqués à la Conduite \& aux Affaires des Nations \& des Souverains (Londres, 1758). The book was actually printed in Neuchâtel in 1757 .

2 On Bourguet see Sophie Bisset, 'Exploring the parameters of the école romande du droit naturel in the Journal helvétique: the case of Louis Bourguet's "Four letters on Leibniz"' in Lectures du 'Journal helvétique, 1732-1782, ed. Séverine Huguenin and Timothée Léchot (Geneva: Slatkine, 2016), 315-328; Sophie Bisset, 'The reception of Pufendorf and Leibniz in the early école romande du droit naturel: Jean Barbeyrac and Louis Bourguet,' Etudes Lumièrs. Lausanne, no. 7, février 2019, http://lumieres.unil.ch/fiches/biblio/9475/; Simone Zurbuchen, 'Bourguet, Louis (1678-1742),' in The Dictionary of Eighteenth-Century German Philosophers, ed. Heiner F. Klemme and Manfred Kuehn, vol. 1 (London: Continuum, 2010), 135-137. 
nations he wanted to ensure a reception in the polite world. To achieve this, he renounced his original idea to simply translate Wolff's Jus gentium methodo scientifica pertractatum (1749) into French. In order to get rid of the mathematical method the German philosopher applied, he eventually decided to write a work of his own. The extent to which Vattel was indebted to Wolff is further documented by his critical observations on Wolff's work on the law of nature. ${ }^{3}$ While it is most likely that Vattel studied natural law with Burlamaqui in Geneva, he never attested any close affiliation with Samuel Pufendorf's theory of the law of nature and nations, which was mainly taught in the Suisse romande as well as in other parts of the Helvetic Confederation. Quite to the contrary, Vattel showed a great deal of interest in Leibniz' philosophy, which he vindicated in his Défense du système Leibnizien contre les objections et les imputations de Mr. de Crousaz (1741), and he attempted to defend a middle position in the famous controversy on the principle of obligation between Barbeyrac and Leibniz in his Essai sur le fondement du droit naturel (1747). ${ }^{4}$ It may well be that his endeavour to secure Leibniz from Barbeyrac's vigorous critique was influenced by Bourguet, who was also a great admirer of Leibniz, but eventually nuanced his position for prudential reasons, when he considered applying for Barbeyrac's position at the Academy of Lausanne upon the latter's departure in 1718.5

So far, much of the research devoted to the Swiss school (or école romande) of natural law has focused on natural and politic law. Almost nothing is known about the teaching and publishing activities related to the law of nations prior to the publication of Vattel's treatise. ${ }^{6}$ Curiously, the new edition of Hugo Grotius' De jure belli ac pacis, which appeared in five volumes in Lausanne in 1751$175^{2}$, has never been commented upon, although it was later praised as one of the best editions of this work. ${ }^{7}$ In what follows, I will first provide information

3 Vattel drafted his Questions de droit naturel, et observations sur le Traité du droit de la nature de M. le baron de Wolf in 1753 . The book was published in 1762.

4 On Vattel's career see Simone Zurbuchen, 'Emer de Vattel on the Society of Nations and the Political System of Europe,' in System, Order, and International Law, ed. Stefan Kadelbach, Thomas Kleinlein and David Roth-Isigkeit (Oxford: Oxford University Press, 2017), 263-282, and further references there.

5 Bisset, 'The reception of Pufendorf and Leibniz,' p. 5.

6 For a brief overview, see Peter Haggenmacher, 'Völkerrecht,' in Historisches Lexikon der Schweiz, accessed 2 January 2018, http://www.hls-dhs-dss.ch/textes/d/D9619.php.

7 In his German translation of Grotius' work, published in 1869, J.H. von Kirchmann stresses the originality of the Lausanne edition: 'Das Werk, das hier zunächst interessiert, "Ueber das Recht des Krieges und des Friedens", ist bisher noch nicht in das Deutsche übersetzt worden. Die besten Ausgaben des Originaltextes sind die von Gronow, mit schätzbaren Anmerkungen, von Barbeyrac und von Samuel Cocceji. Letztere ist in Lausanne in 4 Quartbänden 
about the teaching and the literary production related to the law of nations in the Suisse romande and hence the context of the Lausanne edition of Grotius. We will see that the distinguishing feature of this edition is the incorporation of the extended commentaries on Grotius' theory of the law of nature and nations by Heinrich and Samuel Cocceji (father and son), which had first been published in Breslau (Wratislavia) as Grotius illustratus (1744-1752). ${ }^{8}$ Taking account of the Coccejis' vigorous critique of Grotius' dualist account of the law of nations, I will proceed, secondly, to a comparative account of the definition of the law of nations from Grotius via Pufendorf, Barbeyrac and Burlamaqui to Vattel. This conceptual analysis will lead to the conclusion that while the Lausanne edition of Grotius was most likely undertaken for commercial reasons, it also strengthened the position of the adherents to Samuel Pufendorf's naturalist theory of the law of nations, who were predominant in the école romande, until Vattel resumed the Grotian tradition in his highly influential Law of Nations.

\section{The Lausanne Edition of Grotius in Context}

It is useful to recall that, in contradistinction to the Academy of Lausanne, which created its first law chair in 1711, when Barbeyrac was appointed, its Genevan counterpart had established its law school during the Reformation. This helps to explain why the law of nature and nations was taught in Geneva even before Barbeyrac's French translations of Pufendorf's works became the main reference for teaching the subject. ${ }^{9}$ Indeed, two of the Geneva law professors probably began teaching the law of nations on the basis of Grotius' $D e$ jure belli ac pacis in the last quarter of the seventeenth century. One of them was Philipp Reinhard Vitriarius (1647-1720), who had studied law with Johann Heinrich Boecler at the University of Strasbourg and was professor of civil law

erschienen. Schon Gr. hatte seinem Werke bei einer späteren Auflage im Jahre 1632 Noten beigesetzt. Diese und die von Gronow sind in der Ausgabe von Cocceji mit abgedruckt und ihnen sind weitläufige Excurse über naturrechtliche Fragen beigegeben'. See Hugo Grotius, Recht des Krieges und des Friedens, transl. J.H. von Kirchmann, vol. 1 (Berlin: L. Heimann, 1869), 14 .

8 Henrici de Cocceji, Grotius illustratus seu commentarii ad Hugonis Grotii de juri belli ac pacis libros III, ed. Samuel de Cocceji, 4 vols. (Wratislaviae: Johann Jacob Korn, 1744-1752).

9 In what follows, I will focus on the law of nations only. For a general account of the teaching of the law of nature and nations in the Swiss context see Simone Zurbuchen, "Teaching the Law of Nature and Nations in the Swiss Context,' Etudes Lumières.Lausanne, no. 6, novembre 2018, http://lumieres.unil.ch/fiches/biblio/9472/. 
at the Academy of Geneva from 1677 to 1682 , before he moved to the University of Leiden. In Geneva, Vitriarius taught three courses on the Institutes, i.e. Roman law, and one course on questions of law. The latter was dedicated to the public law of the German Empire, but perhaps also to the law of nature and nations according to Grotius. ${ }^{10}$ I am inclined to think so because he published in 1692 the Institutiones juris naturae et gentium. This book was re-edited several times; in 1745 by Marc-Michel Bousquet in Lausanne, ${ }^{11}$ who also brought out the annotated edition of Grotius. In his Histoire de l'Université de Genève, Charles Borgeaud indicates that Bénigne Mussard (1657-1722), honorary professor of civil law from 1682 to 1685 , was asked to produce the commentary on Grotius' De jure belli ac pacis. ${ }^{12}$ The teaching of the law of nations was later resumed by Burlamaqui, who lectured on the law of nature and nations on the basis of Barbeyrac's translations of Pufendorf's works. ${ }^{13}$

Turning to the Academy of Lausanne, the first text we need to consider is the amply annotated French translation of Grotius' major work on which Barbeyrac was working in Lausanne, Du droit de la guerre et de la paix, first published in Amsterdam in $1724 \cdot{ }^{14}$ It was, however, not Barbeyrac himself, but his successor to the chair of natural law and history, Charles-Guillaume Loys de Bochat (1695-1754), who rendered prominent the law of nations in the Swiss context. Since he is a virtually unknown figure, I will present him here in some detail..$^{15}$

10 Charles Borgeaud, Histoire de l'Université de Genève. L'Académie de Calvin, 1559-1798 (Geneva: Georg \& Cie., 1900), 386-389.

11 Philipp Reinhard Vitriarius, Institutiones juris naturae et gentium [...] ad methodum Hugonis Grotii (Lausanne: Antoine Chapuis, 1745). The publisher, Bousquet, closely collaborated with the printer, Chapuis.

12 Borgeaud, Histoire de l'Université de Genève, 507.

13 In addition to the Principes du droit naturel (1747) and the Principes du droit politique (1751), first translated into English by Thomas Nugent in 1748 and $175^{2}$, and published together in 1763 as Principles of Natural and Politic Law, ed. and with an introduction by Petter Korkman (Indianapolis, IN: Liberty Fund, 20o6), I will also refer below to the Principes du droit de la nature et de gens, ed. by Fortuné-Barthélemy de Félice, 8 vols. (Yverdon: [de Félice], 1766-1768), who referred to Burlamaqui's lecture notes that survived in the library.

14 Hugues Grotius, Le droit de la guerre et de la paix, transl. Jean Barbeyrac (Amsterdam: Pierre de Coup, 1724). See Philippe Meylan, Jean Barbeyrac (1674-1744) et les débuts de l'enseignement du droit dans l'ancienne Académie de Lausanne (Lausanne: F. Rouge \& Cie., 1937), 84-86.

15 On Loys de Bochat, see Jean-François Poudret et al., L'enseignement du droit à l'Académie de Lausanne aux XVIII et XIXe siècles (Université de Lausanne, 1987), 29-38; Meylan, Jean Barbeyrac, 159-171, 208-209; Henry Perrochon, 'Un savant d'autrefois: G.-Ch. Loys de Bochat (1695-1754), Revue historique vaudoise 49 (1941): 29-33; [J.A.D. 
Loys de Bochat first studied philosophy with Jean-Pierre de Crousaz in Lausanne, then theology at the University of Basel. Due to ill health, he needed to return home, and he studied law under Barbeyrac. In 1716, he continued his study of law at the University of Basel, and in 1717 he defended his dissertation there, De optimo principe. ${ }^{16}$ In the same year, the chair of natural law and history at the Academy of Lausanne became vacant, and both Barbeyrac and de Crousaz petitioned the authorities of Berne on behalf of Louis Bourguet's candidacy for the chair. Given that Barbeyrac's main argument against the appointment of his former student was that the latter had 'studied law for two years at most' with 'no hint of erudition', ${ }^{17}$ it is not surprising that the Bernese authorities encouraged Loys de Bochat to complete his education abroad, by granting him a stipend. Before he began teaching in Lausanne, he studied at different universities, notably at Halle and at Leiden.

As professor in Lausanne (1721-1740), Loys de Bochat became well known for the new method he introduced in his public courses on history, whereby historical events were considered to be 'secondary sources of instruction' and there was discussion of 'how the principles of natural law, of the law of nations, of public law, of politics and morality' were to be applied and developed in various contexts. ${ }^{18}$ The branch of history he was most interested in and which had so far not been taught at Lausanne was ecclesiastical history. In 1733, the public course on natural law was replaced by the course on ecclesiastical history. In his private courses, which took up several hours a day, Loys de Bochat dealt with natural and civil law. From 1725 onwards, he functioned as assessor of the local law court; when he was appointed lieutenant baillival (that is, local substitute of the reeve), he renounced the chair at the Academy. In 1750, he was eventually appointed contrôleur général. In addition to his public positions, Loys de Bochat founded, together with his friend Gabriel Seigneux de Correvon, the journal Bibliothèque italique ou Histoire littéraire de l'Italie (1728-1734), published by Marc-Michel Bousquet in Geneva. ${ }^{19} \mathrm{He}$ also initiated the foundation

Clavel de Brenles], Eloge historique de Monsieur Charles Guillaume Loys de Bochat (Lausanne: Antoine Chapuis, 1755).

16 Charles-Guillaume Loys de Bochat, Dissertatio inauguralis juridica de optimo principe (Basileae: typis Friderici Lüdij, 1717).

17 Barbeyrac in a letter to Bourguet, 28 th May 1717 , quoted by S. Bisset, "The reception of Pufendorf and Leibniz,' p. 3. On Loys de Bochat's nomination see also Meylan, Jean Barbeyrac, 159-166.

18 Clavel de Brenles, Eloge historique, 9-10.

19 On this journal see Francesca Bianca Crucitti-Ullrich, 'Bibliothèque italique (1728-1734),' in Dictionnaire des Journaux 160o-1789, accessed 2 February 2018, http://dictionnairejournaux.gazettes18e.fr/journal/o165-bibliotheque-italique. 
of the book store of the publishing company Marc-Michel Bousquet \& Cie. at Place St.-François in Lausanne in 1736, and he became an influential member of the Société du comte de la Lippe, a local society founded in 1742 in Lausanne that took care of the education of the young earl Simon August von LippeDetmold. ${ }^{20}$

It seems that Loys de Bochat got involved with the law of nations when he adopted the task of defending the Swiss practice of mercenary service abroad against an anonymous critique, first published as a short letter in the Journal littéraire de la Haye (1724) and addressed to Jean-Pierre de Crousaz. This critique was at the origin of a lengthy debate that Loys de Bochat made public in a volume entitled Ouvrages pour et contre les services militaires étrangers, considérés du côté du droit et de la morale $(1738) .{ }^{21}$ His vindication of Swiss mercenary service is interesting: while clearly motivated by the intention to save the reputation of the Swiss abroad as reliable and faithful partners, ${ }^{22}$ in the bulk of his lengthy reply Loys de Bochat deals with those general principles of natural law suitable for justifying the Swiss practice and attempts to demonstrate that these principles are very solid indeed. Once he had published a first dissertation in response to the anonymous letter, where he already relied extensively on the natural law literature available on the subject - notably on Gentili, Grotius, Pufendorf and their commentators - he went on reading all of the systems of law of nature and of public law subsequently available, as well as commentaries on earlier works on that matter, in order to check whether any of them questioned the main arguments he defended. ${ }^{23}$ Hence his first dissertation, as well as the subsequent pieces on more specific issues raised by a critique (again anonymous) of that work, constitute a kind of bibliography of textbooks and dissertationes to which Loys de Bochat referred in order to prove his case, that is, to demonstrate that allowing mercenaries to enrol in foreign armies as well as serving in mercenary troops as a soldier was legitimate both on juridical and on moral grounds. One gets the impression that he

20 Transcriptions of the minutes of this society are available on the website 'Lumières. Lausanne', accessed 2 February 2018, http://lumieres.unil.ch/projets/lippe/.

21 Charles-Guillaume Loys de Bochat, Ouvrages pour et contre les services militaires étrangers, 3 vols. (Lausanne, Genevae: Marc-Michel Bousquet \& Cie., 1738).

22 See Meylan, Jean Barbeyrac, 207-210.

23 Loys de Bochat, Ouvrages pour et contre les services militaires étrangers, vol. 1, 'Préface', XIV: 'Depuis l'impression de ma Dissertation, il s'est publique quelques Systèmes de Droit Naturel \& Public, \& quantité de Notes sur des Ouvrages qui en ont traité. Je crois d'avoir vû tous ces Livres. Aucun n'a touché à la Thèse que je soutiens. N'est-ce point là encore une présomption en sa faveur?'. 
had Barbeyrac's verdict on his poor erudition constantly before his eyes when replying to his critics.

Loys de Bochat also adopted a leading role in a discussion launched by the Société du comte de la Lippe on the balance of power in Europe and the question of whether a preventive war against a neighbouring state which augments its power and threatens weaker states by oppression is legitimate according to the law of nations. ${ }^{24}$ His introductory statement to the debate testifies again to his profound knowledge of the literature on the law of nations. Hence, he first deals with Pufendorf and Grotius, 'the two restorers of natural law', and their commentators, who would have argued that if a state increases its power and is hence in a position to harm its neighbours, this fact alone does not provide the latter with a just cause of war. He then considers the seemingly opposite position defended by Alberico Gentili, Thomas Hobbes and Nicolaus Hieronymus Gundling, with the intention to demonstrate that, all things considered, the latter were of the same opinion as the former.

Loys de Bochat's repeated engagement with questions related to the law of nations and just war, which is further attested by a former student's doctoral dissertation on ambassadors, ${ }^{25}$ help to explain his active participation in the new edition of Grotius' De jure belli ac pacis, published by Marc-Michel Bousquet in Lausanne in $175^{-1}-175^{2}$. The latter was a very able bookseller, who created his first publishing house in Geneva in 1724 with two business associates. As we have seen, he published the journal Bibliothèque italique. After a breakup with his associates, Bousquet settled in Lausanne upon an invitation from Loys de Bochat, where he closely collaborated with the printer Antoine Chapuis. ${ }^{26}$ Bousquet's business was largely based on the practice of exchange with other publishers and on creating networks with reliable customers abroad. This is why he travelled all over Europe. In 1750, he went on a tour of Italy with the intention of obtaining subscriptions for his publication of a Latin edition of Grotius. In the first volume of the edition, we find a salutation, signed by Bousquet, in which the publisher thanks the Italian subscribers for their prepayments and announces that their names will be published at the

24 See Simone Zurbuchen, 'Théorie de la guerre juste et balance du pouvoir en Europe', in L'Europe en province: la Société du comte de la Lippe (1742-1747). Actes du colloque organisé à l'Université de Lausanne du 25 au 26 juin 2009, ed. Béla Kapossy et al. (Lausanne: Lumières. Lausanne, 2013), http://lumieres.unil.ch/fiches/biblio/5687/.

25 Abraham Daniel Clavel de Brenles, De exemptione legatorum, a foro criminali ejus ad quem missi sunt (Marburg: Phil. Casim. Muller, 1740).

26 On Bousquet's publishing companies see Silvio Corsini, 'Vint-cinq ans d'édition et d'imprimerie à Lausanne au siècle des Lumières: le libraire Marc-Michel Bousquet, 17361761, Revue historique vaudoise 120 (2012), 23-53. 
end of the fourth volume. ${ }^{27} \mathrm{He}$ kept his promise and one finds the list of Italian pre-payers there.

What makes the Lausanne edition of Grotius highly original is the incorporation of numerous annotations and commentaries, which had been published before but which were now assembled in the five-volume edition: volumes 1-4 comprise the text of Grotius' work, and on the bottom of each page annotations by Gronovius and by Barbeyrac appear. Heinrich Cocceji's commentaries and his son's additional remarks follow at the end of each chapter. To this, the editors joined, in volume 4, Grotius' dissertations Mare liberum and De aequitate, indulgentia, et facilitate. Volume 5 contains 12 dissertations of Samuel Cocceji, entitled Introductio. In his note of thanks, Bousquet stresses that he had to correct thousands of errors contained in the earlier, Breslau edition, ${ }^{28}$ and from the address to the reader we can gather that Loys de Bochat reorganized Samuel Cocceji's commentaries in order to avoid repetitions. ${ }^{29} \mathrm{~A}$ glimpse at the dissertations suffices to show that Samuel Cocceji availed himself of his father's comments on Grotius to present his own theory of the law of nature and nations, which he had already developed in his earlier writings, and which also attest to some disagreement with his father. In the next section, I will proceed to a selective reading of the Coccejis' theories of the law of nature and focus exclusively on their account of the law of nations. As we will see, they unanimously and vigorously rejected Grotius' account of the law of nations.

To properly assess the Coccejis' critique of Grotius, let us first recall that a major innovation associated with the law of nations in the seventeenth century consisted in 'a rethinking of the relationship between natural law and its less regarded junior partner, the jus gentium. ${ }^{30}$ As Stephen C. Neff has shown, the pulling apart of the formerly tight bonds between these two kinds of law marked 'the birth of international law in its modern sense.. ${ }^{31}$ In general terms, the distinction between natural law and jus gentium can be described

27 Hugo Grotius, De jure belli ac pacis libri tres, vol. 1 (Lausanne: Marc-Michel Bousquet \& Cie., 1751), 'Epistola dedicatoria'.

28 Ibid.

29 Ibid., LXII.

30 Stephen C. Neff, Justice among Nations. A History of International Law (Cambridge, MA: Harvard University Press, 2014), 151.

31 Ibid. 
as resting on three assumptions: first, jus gentium is not derivable from natural law, but rests on human experience and free will; secondly, in contradistinction to the law of nature, jus gentium is exclusively applicable to states as such and not to individual persons, or private parties; and thirdly, jus gentium cannot be conceived independently from natural law, but rather works in a kind of partnership with the latter and supplements it in certain respects. The emergence of such a dualist conception of the law of nations was a complicated matter. It was accompanied by the use of sometimes confusing terminology, not least because many of the natural lawyers referred back to Roman law in order to show that what they had in mind differed from the Roman-law notion of jus gentium..$^{32}$ Francisco Suárez was the first author to introduce a clearcut distinction between the law of nature and jus gentium along the lines just described. While Suárez named the positive law between states jus gentium proper', Grotius designated it by the expression 'voluntary (or volitional) law of nations' (jus gentium voluntarium). ${ }^{33}$ Although in De jure belli ac pacis the distinction between Roman-law jus gentium and the voluntary law of nations is not spelled out without ambiguities, Grotius clearly followed Suárez in developing a dualist conception of the law of nations, comprising those parts of natural law which are relevant for relations between states on the one hand, and the manmade law of nations, which arises out of agreement between states, on the other. This dualist conception, which exerted a major influence on later writers, is known today as the 'Grotian' approach to international law. ${ }^{34}$

Grotius deals with the law of nations in the Prolegomena, assigning it a role similar to that of municipal or civil law. ${ }^{35}$ He first explains that the bodies of municipal law arose from the promise explicitly or implicitly made by men, who assembled themselves within a group, to conform to the determination of that group or those men to whom the authority had been transferred. This obligation of men to one another rested on the natural law rule 'to abide by

\footnotetext{
32 See Neff, Justice among Nations, $15^{1-153 .}$

33 Ibid., 156.

34 Ibid., 159-16o, 163.

35 Grotius' concept of the law of nations is a complex matter. The goal of the following paragraphs consists exclusively in presenting some of the key elements later scholars commented upon in some detail. For a recent account of Grotius' law of nature, which also accounts for Grotius' earlier writings, see Stafan Kadelbach, 'Hugo Grotius: On the Conquest of Utopia by Systematic Reasoning,' in System, Order, and International Law. The Early History of International Legal Thought from Machiavelli to Hegel, ed. Stefan Kadelbach, Thomas Kleinlein and David Roth-Isigkeit (Oxford: Oxford University Press, 2017), 134-159.
} 
pacts.' ${ }^{36}$ For that reason, nature would have to be considered 'the great-grandmother of municipal law'. Grotius describes the function of municipal law in terms of a reinforcement of natural law when he asserts that the association of men and the subjection to authority 'have their roots in expediency'. For this reason, those who prescribe laws 'have, or ought to have, some advantage in view'. ${ }^{37}$ Grotius then introduces the 'law of nations' or 'the body of law which is maintained between states':

But just as the laws of each state have in view the advantage of the state, so by mutual consent it has become possible that certain laws should originate as between all states, or a great many states; and it is apparent that the laws thus originating had in view the advantage, not of particular states, but of the great society of states. And this is what is called the law of nations, whenever we distinguish that term from the law of nature. ${ }^{38}$

Grotius further explains the analogy between municipal law and the law of nations in the first book of his treatise, where he introduces the expression 'voluntary (or volitional) law' (jus gentium voluntarium) for designating a kind of law which has its origin in the human will. ${ }^{39}$ Beginning again with municipal law, which he explains in the same way as in the Prolegomena, he then introduces two other bodies of human voluntary law, which are respectively narrower or broader in scope than municipal law. The former 'comprises the commands of a father, of a master and all commands of a similar character', and the latter is the 'law of nations', i.e. 'the law which has received its obligatory force from the will of nations, or of many nations'. Grotius explains the qualification 'of many nations' by observing that, with the exception of the law of nature, 'which is also frequently called the law of nations', hardly any law would be common to all nations, and he acknowledges that the voluntary law of nations is not necessarily the same in all parts of the world. ${ }^{40}$ This latter remark is in tension with the paragraph in the Prolegomena where Grotius alludes to the advantage of the 'great society of states', which seems to suggest a universally applicable law of nations, that is, one which is binding on all states.

36 Hugo Grotius, De jure belli ac pacis libri tres, transl. of the ed. of 1646 by Francis W. Kelsey (The Classics of International Law, Oxford: Clarendon Press, 1925), vol. 2, 'Prolegomena', $\S 15,14-15$.

37 Ibid., § 16, 15 .

$38 \quad$ Ibid., § 17, 15 .

39 Grotius, De jure belli ac pacis, book I, chap. I, § XIII, 44.

$40 \quad$ Ibid., § XIV, 44. 
Grotius makes it very clear that the voluntary law originates directly in the will of nations, and indirectly in the natural law rule to abide by pacts, and he also admits that the mutual consent between nations can only be inferred from practice. Hence, he likens the law of nations to 'unwritten municipal law' and describes it - referring to the Church father Chrysostom - as 'the creation of time and custom.41 This body of law would be found in custom and in the testimony of those who are skilled in law. While this reference to custom is coherent with the assumption of an implicit or tacit consent among a great many nations, it also contributes to rendering ambiguous his concept of the law of nations. For Grotius also uses the notion jus gentium to designate the body of law the Romans called the law of nations, that is, the law the Romans applied not just to their own people but to many surrounding nations as well. ${ }^{42}$ Although at some places Grotius explains very clearly that this Roman jus gentium 'is not international law, strictly speaking, for it does not affect the mutual society of nations in relation to one another' and is therefore 'improperly' called 'law of nations', ${ }^{33}$ he also renders ambiguous his own notion of the law of nations. This is mainly so because he refers as well to 'common custom' when explaining the Roman-law use of the term. ${ }^{44}$ As Neff has aptly explained, the Roman-law notion of jus gentium does, however, not arise out of agreement between states and therefore does not rest on the will of nations. It rather 'arises out of separate unilateral enactments by states - with the contents of those unilateral enactments "matching up" with one another. 45

In view of the development of the law of nations from the eighteenth to the nineteenth century and the constitution of the law of nations as a discipline increasingly distinct from the law of nature, Grotius' dualist conception of the law of nations, comprising both the law of nature applied to states and the voluntary law governing exclusively the relationship between states, is clearly a major innovation. It was, however, challenged by a large group of authors who, following Thomas Hobbes' stripped-down view of natural law and natural right, contested the very existence of a voluntary law of nations. The leading figure of this rival school of international thought was Samuel Pufendorf, who maintained that natural law was the only law of universal application between states. In The Law of Nature and Nations, he introduces the discussion of

\footnotetext{
41 Ibid.

42 On this ambiguity see Neff in his introduction to Hugo Grotius, On the Law of War and Peace, ed. Stephen C. Neff (Cambridge: Cambridge University Press, 2012), XXXII-XXXIII.

43 Grotius, De jure belli, vol. 2, book II, chap. viII, § I, 295.

44 Ibid.

45 Neff, introduction to Grotius, On the Law of War and Peace, XXXII.
} 
Grotius' voluntary law of nations with the following question: 'Whether or no there be any such thing as a particular and positive Law of Nations, contradistinct to the Law of Nature. ${ }^{46}$ He first refers to Hobbes' distinction between the natural law of men, and the natural law of states (commonly called the law of nations), the precepts of which are the same because, once instituted, states assume the proprieties of men. He then fully subscribes to this doctrine and denies the existence 'of any other voluntary or positive Law of Nations, properly invested with a true and legal Force, and obliging as the Ordinance of a superior Power. ${ }^{47}$ In Pufendorf's view, matters such as the way in which things are acquired or contracts, which are commonly referred to the law of nations, belong either to natural law or to the civil laws of the countries where they are observed. He thus does not deny that there may be agreements among many states on such matters, but he contests that it is not proper or fair to constitute these as a peculiar and distinct Species of Law', for ordinances common to many nations would not arise 'in mutual Covenant or Obligation'48 They rather depend on accidental agreement among legislators, who can alter them without advising with their neighbours. In the same context, Pufendorf also recalls the Roman-law concept of jus gentium, which included all foreigners, while the civil law was proper only to Roman citizens. This kind of law, he insists, had, however, nothing to do with what Grotius called the voluntary or positive law of nations. ${ }^{49}$

Concerning the latter, Pufendorf uses several examples to show that matters Grotius dealt with under the heading of the voluntary law of nations in fact concern the law of nature. Thus, he argues that the persons of ambassadors 'are sacred and inviolable [...] by the meer Law of Nature, ${ }^{50}$ because they are necessary for the procuring and preserving of peace by leagues and covenants, which are themselves enjoined on men by the law of nations. Further, he argues that the right of burial, which Grotius also considers to belong to the voluntary law of nations, could very well be referred to the duties of kindness and humanity, which are part of the law of nature. ${ }^{51}$ Pufendorf proves to be highly critical of the many authors who would rank under the title of the

46 Samuel Pufendorf, Of the Law of Nature and Nations, transl. Basil Kennett, 4th ed. (London: J. Walthoe, R. Wilkin, J. and J. Bonwicke, S. Birt, T. Ward and T. Osborne, 1729), book II, chap. III, § XXIII, 149.

47 Ibid., 15 o.

48 Ibid.

49 Ibid., 150-151.

$50 \quad$ Ibid., 151.

51 Ibid., $15^{2}$. 
law of nations the customs mutually observed by tacit consent among 'People pretending to Civility'. Alluding to examples of rules observed in the conduct of war, which Machiavelli described in The Prince, he mocks clement practices such as exempting certain things or persons from martial violence, or the taking of prisoners (who are afterwards released without ransom) instead of killing enemy soldiers, as mere niceties allowing those who fight an unjust war 'to appear wicked with some kind of Temper and Moderation'.52 In Pufendorf's view, rules customarily observed in war cannot constitute any law or universal obligation, since any party has the right to absolve themselves from restraints which rest on tacit agreement. This would explain why one finds such practices worn out by time and replaced by contrary practices.

Pufendorf's 'naturalist' account of the law of nations, according to which jus gentium is nothing other than the law of nature applied to states, had a strong influence in Brandenburg-Prussia, notably on Christian Thomasius and his followers Johann Franz Budde and Nicolaus Hieronymus Gundling, who taught natural law at the University of Halle, and on Johann Gottlieb Heineccius at the Universities of Frankfurt an der Oder and Halle. ${ }^{53}$ His rejection of the voluntary law of nations was further strengthened by his French translator, Barbeyrac, who explicitly secured Pufendorf's position in a note to The Law of Nature and Nations and also inserted a lengthy comment on the same issue in his translation of Grotius' work. Hence, we read in a note to the paragraph in the first book of Dejure belli we have been considering above: 'The Positive Law of Nations, distinct from the Law of Nature, is a mere chimera. ${ }^{4}$ Barbeyrac goes on to explain that he does not wish to deny that all nations have to observe certain principles and rules in regard to one another, and that this may well be called the law of nations. He insists, however, that these rules are the same as those of the law of nature properly so called and that the obligation to respect them does not arise, as Grotius held, from the consent of nations. Regarding the customs respected by the generality of nations, which are not enjoined on them by the law of nature, Barbeyrac does not deny that any given nation may be obliged to submit to them as long as it does not give any proof to the

52 Ibid., 151.

53 See Tetsuya Toyoda, Theory and Politics of the Law of Nations. Political Bias in International Law Discourse of Seven Court Councilors in the Seventeenth and Eighteenth Centuries (Leiden, Boston: Martinus Nijhoff, 2011), 140-1. Johann Peter von Ludewig, who also taught law at the University of Halle, defended however the voluntary law of nations (ibid., 140-141).

54 Grotius, Le droit de la guerre et de la paix, livre I, chap. I, § XIV, note 3, 56: 'Le Droit des Gens, Positif, \& distinct du Droit Naturel, est une pure chimére'. 
contrary. In this case the obligation would, however, arise 'from this tacit and private agreement, without which the Customs in question have no force. .55 The meaning of this 'tacit and private agreement' can be further elucidated by what Barbeyrac says in the corresponding note to Pufendorf's treatise, to which he explicitly directs the reader in his Grotius edition. Here Barbeyrac insists on the difference between an agreement and a law: while an obligation can arise from (private) agreement, this cannot produce 'a particular Law distinct from the natural'. Like any other contractual agreement, an agreement to submit to a custom 'must be referred to that general Law of Nature which obliges us to keep all Covenants.' ${ }^{56}$ In other words, as long as all peoples are naturally equal, there is neither a superior nor an inferior, and consequently no people can impose law upon another. It is also impossible that all peoples, taken together, impose laws on themselves.

Seen against this background of debates on Grotius' voluntary law of nations, the position defended by the Coccejis amounts to a strengthening of the 'naturalist' school. In a note to the same paragraph in De jure belli ac pacis, which provoked Barbeyrac's denial of the voluntary law of nations, Heinrich Cocceji observed that this whole inquiry was superfluous, because a human law that obliges all nations did not exist. There could be no question of the civil law in this place. ${ }^{57}$ And Samuel added in his additional note that he would deal at length with Grotius' system of the voluntary law in the narrower and in the broader sense of the term in his fourth dissertation. Commenting on paragraph 17 of the Prolegomena, he would demonstrate that there does not exist any such jus gentium, that this was an invention of Tribonian, and that therefore all disputes about this law are superfluous. ${ }^{58}$

Only a few scholars have dealt with the Coccejis' theory of law of nature and nations. ${ }^{59}$ Samuel Cocceji is well known for his politico-juridical career in the

55 'Ainsi toute obligation vient de cette convention tacite \& particulière, sans laquelle les Coûtumes, dont il s'agit, n'ont aucune force'. (Ibid.)

56 Pufendorf, Of the Law of Nature and Nations, book II, chap. III, § XXIII, note 2, $15^{\circ}$.

57 Grotius, De jure belli ac pacis libri tres, vol. 1, 58: 'Tota haec tractatio supervacua est, quia jus humanum, quod omnes gentes obliget, non datur : Jus civile autem hujus loci non est'.

$5^{8}$ Ibid., 59: 'Systema Grotii de jure gentium voluntario, eoque tum latius patente, tum arctiori, late exposuimus in Dissertatione Prooemiali IV. ejusque compendium exhibuimus in not. ad. Proleg. $\$ 17$. Simulque demonstravimus, tale jus gentium non dari [...] illudque inventum esse Triboniani. [...] Adeoque omnia, quae hic de tali jure disputantur, supervacua sunt'.

59 For an overview on their career and writings see Oliver Peglow: 'Cocceji, Henrich von,' in The Dictionary of Eighteenth-Century German Philosophers (Oxford: Continuum, 2011), accessed 3 February 2018: http://www.oxfordreference.com/view/10.1093/acref/ 9780199797097.001.0001/acref-9780199797097-e-o1oo, and Oliver Peglow: 'Cocceji, 
service of Frederick Wilhem I and of Frederick II, as well as for his work devoted to the reorganization of the juridical system in Prussia. Before embarking on this career, Samuel was, however, like his father Heinrich before him, a professor of law at the University of Frankfurt an der Oder, where he had studied law and obtained his doctoral degree with a dissertation entitled Tractatus Juris Gentium, de principio juris naturalis unico, vero et adaequato, which was published in two parts in $1702 .{ }^{60}$ In the first part of the dissertation, he deals with fundamental questions such as the very existence of the law of nature and the principle on which it rests. Some disagreements with his father notwithstanding, he subscribes to the latter's critique of the idea to found the law of nature on socialitas and defends God's will as sole principle of natural law. In the second part of the dissertation, he defends his account of the law of nature against an anonymous author (who in fact was Leibniz), against Johann Peter von Ludewig and against Johann Nicolaus Hertius. ${ }^{61}$ In 1713 , Samuel Cocceji published a commentary on Justinian's Institutes, entitled Jus civile controversum, and in 1740 the Elementa jurisprudentiae naturalis et Romanae, which he later included, under the title 'Novum Systema Justitiae Naturalis \& Romanae', in the dissertations appended to the Grotius edition. ${ }^{62}$

The Coccejis' pronounced and radical critique of Grotius' voluntary law of nations has only recently aroused scholarly attention. Tetsuya Toyoda attempted to show that Samuel Cocceji rejected the voluntary law with the intention to please Frederick II, who 'disturbed the then fragile balance of power in Europe' when he started the First Silesian War (1740-1741). ${ }^{63}$ While Toyoda

Samuel von,' accessed 3 February 2018, ibid.: http://www.oxfordreference.com/view/ 10.1093/acref/9780199797097.001.0001/acref-9780199797097-e-0101. In the Englishlanguage literature, Samuel Cocceji's natural law theory has mainly been studied with an interest in the use Adam Smith made of it in his Lectures on jurisprudence. See Knud Haakonssen, Natural Law and Moral Philosophy. From Grotius to the Scottish Enlightenment (Cambridge: Cambridge University Press, 1997), 129-148; Ernest Metzger, 'Adam Smith's historical jurisprudence and the "method of the civilians", in Smith in Glasgow 'og, 31 March-2 April 2009, Glasgow, UK, accessed 3 February 2018, http://eprints.gla.ac.uk/ $25492 /$.

6o Samuel Cocceji, TractatusJuris Gentium, de principiojuris naturalis unico, vero, et adaequato (Frankfurt an der Oder: Jeremiae Schreyi Haered. \& Joh. Christoph. Hartmann, 1702).

61 On the controversy between Leibniz and the Coccejis see Hans-Peter Schneider, 'Die wissenschaftlichen Beziehungen zwischen Leibniz und den beiden Cocceji (Heinrich und Samuel), in Humanismus und Naturrecht in Berlin-Brandenburg-Preussen, ed. Hans Thieme (Berlin, New York: de Gruyter, 1979), 90-102.

62 This was the twelfth dissertation, much longer than the other dissertations.

63 Toyoda, Theory and Politics of the Law of Nations, 137. Toyoda mentions in the same context (ibid., 139) that Samuel Cocceji published pamphlets legitimizing the Prussain seizure of Silesia in order to obtain the Frederick II's patronage. 
seems to acknowledge that Samuel had already mentioned the voluntary law of nations in his dissertation of 1702 and again in the Jus civile controversum of $1713,{ }^{64}$ he downplays the continuity between these latter works and the Introductio, i.e. the 12 dissertations he appended to his father's commentary on Grotius' work, where the rejection of the voluntary law of nations became much more important. What is more, he erroneously assumes that Samuel would have published the dissertation on the voluntary law already in the Elementa, which he published in 1740. This seems, however, not to be the case, for the latter comprised only the 'Novum Systema', which was to become the twelfth dissertation. ${ }^{65}$ Toyoda has, however, a good point when he claims that Samuel Cocceji's critique of Grotius' concept of solemn war, which rested on the voluntary law of nations, proved to be useful for justifying Frederick II's conquests in Silesia. In the ninth dissertation Cocceji argued, indeed, that a war cannot be considered just on both sides and that the justness of the cause of war remains suspended until God determines who has won the war by giving him the ultimate victory. ${ }^{66}$

Let us now have a closer look at Samuel Cocceji's fourth dissertation, which consists of two chapters. Before he gets to a detailed analysis of Grotius' account of the voluntary law of nations in the first chapter, ${ }^{67}$ he introduces the jus humanum voluntarium or jus gentium secundarium, which - as the doctores would hold - the human nations constituted between them 'as occasion and the necessities of human life required'.68 He goes on to observe that since the nations never got together and constituted such a law by common consent, it would be difficult to know what this law is and how it can be proved. He then recalls how his father proposed to deduce this law (by referring to the state of corruption) and how he conceived it himself in his earlier writings, where he likened the secondary law of nations to the law the Romans applied not just to their own people but to foreigners (extraneos) as well, which they admitted to this law 'out of necessity, and common utility'. ${ }^{69}$ This explanation of the jus gentium implied that there did not arise any obligation between the

\footnotetext{
64 Ibid., $142-143$.

65 See Metzger, 'Adam Smith's historical jurisprudence,' 11-12.

66 Toyoda, Theory and Politics of the Law of Nations, 145-148. S. Cocceji, 'Dissertatio prooemialis IX,' § CLXVIII, 242-243.

67 On various aspects of this chapter see Toyoda (note 66 above), and Walter Rech, Enemies of Mandkind. Vattel's Theory of Collective Security (Leiden/Boston: Martinus Nijhoff, 2013), 83-95.

68 S. Cocceji, 'Dissertatio prooemialis IV,' § I, 78: 'quod usu exigente, \& necessitatibus humanis'; this expression refers to the Institutes, book I, title II, 2.

69 Ibid., § IV, 79 .
} 
nations and that the Roman people could therefore abrogate that law ad libitum and exclude the foreigners from it with the same right as they admitted them. Samuel Cocceji eventually adds that this interpretation contradicts the definition of the law of nations proposed by Tribonian, who maintained that the human nations established this law between them. ${ }^{70}$ This is in fact the main thesis the younger Cocceji defends in the second chapter of the dissertation. It rests on an argument about the proper interpretation of the jus gentium in the Corpus juris civilis. He attributes the erroneous definition either to Justinian or to Tribonian - who was named by the emperor Justinian as one of the commissioners charged with preparing the new imperial legal code and compares it to various other definitions of the law of nations in the Digest (or Pandects), which he attributes to Gaius and Hermogenian. Through these comparisons, he aims to demonstrate that, according to the Roman jurists, jus gentium, properly understood, is the same as jus naturae, which is accessible by human reason and does not rest on the nations' will. ${ }^{71}$ The secondary law of nations, which Grotius called jus gentium voluntarium, was a 'monster' which originated in an error of Tribonian. ${ }^{72}$

While we do not know why the Lausanne jurist Loys de Bochat took a specific interest in the Coccejis' comments on De jure belli ac pacis, there is no doubt that the latter strengthened the 'naturalist' account of the law of nations, which remained predominant in the context of the école romande until the publication of Vattel's Law of Nations. As we have seen above, Samuel Cocceji's rejection of the voluntary law of nations confirmed Barbeyrac's own defence of Pufendorf's position against Grotius. Given that Burlamaqui taught the law of nature and nations on the basis of Barbeyrac's French translations of Pufendorf's works, it comes as no surprise that he also identified the law of nations with the law of nature. It is, however, interesting to observe that in contradistinction to Pufendorf, who attached only marginal significance to treaties and to customary practices of states as possible source of law, ${ }^{73}$ Burlamaqui explicitly acknowledges treaty law and customary law as parts of the law of nations. We can summarize his teaching in the following way: ${ }^{74}$ the same law that

70 Ibid. The proposition he attributes to Tribonian refers again to the Institutes, book I, Title II, 2.

71 Ibid., §XXXIII-VI, 91-92.

72 Ibid., §XXXI, 91; §XLVI, 100.

73 Neff, Justice among Nations, 176.

74 I refer here to Jean-Jacques Burlamaqui, Principes du droit de la nature et des gens. Avec la suite du 'Droit de la nature' qui n'avait point encore paru, ed. Fortuné-Barthélemy de Félice, vol. vi (Yverdon: [F.-B. de Félice], 1768), 'Principes du droit des gens,' part I, chap. I, 1-14. Regarding the dissemination of Burlamaqui's thought, one needs of course to refer to 
is called natural law when applied to individuals is called the law of nations when applied to states. The principle of the law of nations is the general law of sociability (sociabilité), which imposes on peoples or on their sovereigns the same duties to which individuals are subject. ${ }^{75}$ Burlamaqui holds that Grotius' view of the positive law of nations - as a kind of human law, which acquired its obligatory force as an effect of the will of nations - is in fact 'a supposition destitute of foundation. ${ }^{76} \mathrm{He}$ develops three arguments against the voluntary law of nations: first, since nations are equal and independent from each other, only God, their common superior, can impose a law binding them all; secondly, if nations establish customs by express or tacit agreements, these practices are not obligatory by themselves, neither universally nor forever, since customs do not impose on nations any necessity to act always in the same way, and neither are other nations obliged to respect them; and thirdly, customs cannot constitute any obligatory rule, since they might be bad or unjust. Burlamaqui mentions as examples the profession of corsair or pirate, which was for a long time considered legitimate on the grounds of a tacit agreement between nations, and the use of poisoned arms in war. As he sees it, these are barbarous practices, which cannot be part of the law of nations. Customs have to be judged on the basis of the law of nature, and nations may be held responsible for respecting them only as long as they do not explicitly renounce them. ${ }^{77}$

Burlamaqui concludes his critique of Grotius with a proposal to reconcile the previous reasoning by distinguishing two kinds of law of nations: first, a law of nations that is universal, necessary and obligatory by itself, and that is the same as the law of nature; and second, another kind of law of nations, which one might call arbitrary and of liberty, founded on an express or tacit convention. This second kind of law is not universal and obliges only those who subject themselves voluntarily to it and only as long as they wish to do so, insofar as the law of nature requires compliance with contracts. ${ }^{78}$

If we consider Burlamaqui's conclusion together with his critique of the voluntary law of nations, it presents itself like a blueprint of Vattel's concept of the law of nations. In contradistinction to the former, however, Vattel defends the voluntary law of nations instead of rejecting it. Indeed, he acknowledges three kinds of law of nations. First is the natural or necessary law of nations

previous editions, above all to Thomas Nugent's English translations. See note 12 above, and Neff, Justice among Nations, 177.

75 Ibid., part I, chap. I, § IV, p. 5 .

76 Ibid., § VII, 8.

77 Ibid., § VII, 8-9.

78 Ibid., § VIII, 9-11. 
which results from the application of the law of nature to states or nations. Like Barbeyrac in the note on Grotius we have been looking at above, Vattel confirms that the law of nations would slightly change when one applies it to states instead of individuals. ${ }^{79}$ The second kind of law of nations is the voluntary law; this is the jus gentium voluntarium which Grotius defended and which the Pufendorfians and the Coccejis deemed to be a 'chimera'. The third kind of law of nations Vattel acknowledges corresponds to Burlamaqui's arbitrary law of nations, which is founded on an express or tacit convention; this is the customary and treaty law. ${ }^{80}$ The fact that Vattel numbers the voluntary law of nations, together with customary and treaty law, among the positive law of nations is at the foundation of much dispute about the proper interpretation of his concept of the law of nations. While many scholars consider his treatise to inaugurate a positivist account of the law of nations, the present reconstruction of the debates surrounding the voluntary law of nations rather suggests that Vattel resumed the dualist conception Grotius had founded by introducing the jus gentium voluntarium. In fact, Vattel conceived of the law of nations as 'double law' by distinguishing the natural or necessary law of nations from the law of nations properly so called, which originates in the common consent of mankind. ${ }^{81}$ While these two kinds of law are universal, customary and treaty law, which also rest on the agreement of nations, are binding only on parties to the agreement in question.

This account of the law of nations corresponds exactly to the division Wolff indicated already on the title page of his Jus gentium (1749), ${ }^{82}$ and this work was indeed Vattel's main reference for developing the law of nations. As I mentioned in the first part of this chapter, Vattel repudiated, however, the mathematical method as well as Wolff's top-down strategy for founding the law of nations. ${ }^{83}$ Hence, he rejected Wolff's proposal to derive the voluntary law of nations from the idea of a civitas maxima, or 'great republic'. In his view, this fiction was neither admissible in itself nor would it ever receive the 'obedient acquiescence of sovereign states', which claimed and actually possessed absolute independence from each other. Instead of deducing the voluntary law of

79 Emer de Vattel, The Law of Nations, ed. and with an introduction by Béla Kapossy and Richard Whatmore (Indianapolis, IN: Liberty Fund, 2008), 'Preface,' 9-10.

8 o Ibid., $15^{-17}$.

81 Ibid., 17. I have dealt with these matters more extensively in Zurbuchen, 'Emer de Vattel on the Society of Nations and the Political System of Europe'.

82 Christian Wolff, Jus gentium methodo scientifica pertractatum, in quo jus gentium naturale ab eo, quod voluntarii, pactitii et consuetudinarii est, accurate distinguitur (Halle: Renger, 1749).

83 I borrow the expression 'top-down strategy' from Neff, Justice among Nations, 181. 
nations from the fiction of a great republic, Vattel develops this law on the basis of the distinction of internal and external right, which he also borrowed from Wolff. This allowed him to explain how the voluntary law of nations works in partnership with the natural or necessary law of nations and supplements it in various respects: what nations may do by internal right is stated in the natural or necessary law; the voluntary law regulates the domain of external right. Whereas the necessary law corresponds to the immutable laws of justice', which enjoin an obligation on the conscience of nations, the voluntary law indicates what needs to be tolerated in a society of free and independent nations. ${ }^{84}$ Vattel makes it very clear that the voluntary law of nations does not rest on the actual consent of nations. The latter are rather presumed to consent to it by the law of nature, which obliges them not to infringe on their common rights, and especially on the right to decide freely about what justice requires them to do or to omit to do when it comes to a dispute between nations. As Neff has rightly observed, Vattel has sometimes been 'misunderstood as a radical champion of state sovereignty'. ${ }^{85}$ While it is true that he insisted on the legal equality of sovereign nations, he did not, however, renounce the idea that the latter remained subject to the natural or necessary law of nations - a law he claimed rested on general principles and demonstration. Given that he relied on examples in modern history to illustrate his doctrine and that he used the notion of the voluntary law of nations as a flexible tool for showing what nations need to tolerate 'through necessity' in order to respect each other as equal and independent, it seems wholly accurate to place Vattel at the midpoint between rationalist top-down deduction and a pragmatist bottom-up approach to international relations. ${ }^{86}$

\section{Conclusion}

As we have seen in section 2 of this chapter, it is not wholly clear for what reasons the Swiss undertook a multi-volume edition of Grotius' De jure belli ac pacis around the middle of the eighteenth century. After all, they must have been aware that this work had already been published many times in Latin, translated into modern languages and explained in a great number of handbooks and

84 Vattel, The Law of Nations, 'Preface,' 14-16.

85 Neff, Justice among Nations, 197.

86 Ibid., 182. 
commentaries. ${ }^{87}$ Although Loys de Bochat, who participated in the preparation of the edition, certainly had his own good reasons for studying the law of nations when he attempted to defend the Swiss practice of mercenary service abroad, it remains unclear why he had a special interest in the Coccejis' highly critical commentary of Grotius' dualist account of the law of nations. Given his involvement in the foundation of the publishing company Bousquet \& Cie. in Lausanne and in light of Bousquet's subscription campaign in Italy, I am tempted to conclude that this Grotius edition was above all undertaken for commercial reasons. Samuel Cocceji's pronounced and radical critique of the voluntary law of nations certainly strengthened the naturalist account of the law of nations of Pufendorf and his adherents, who were indeed predominant in the Swiss school of natural law. It seems, however, that the Coccejis' theories of the law of nature and nations did not have any further influence in the Swiss context. This is certainly due to the immediate success of Vattel's Law of Nations, which appeared only a few years after the Grotius edition was published. Vattel never refers to the Grotius edition in his treatise. So far, almost nothing is known about reception of the Coccejis' theory of the law of nature and nations in the wider European context. As Christoph Link observed, Heinrich Cocceji was a well-known expert on public law in his own time. His fame faded rapidly, however, because of his son Samuel, who published the commentary on Grotius after his death and thus made the father speak through the son. What is more, Heinrich's historical foundation of the jus publicum RomanoGermanicum, which was innovative in his own time, was criticized in the nineteenth century by representatives of the historical law school and thus fell into near complete oblivion. 88

In contradistinction, Samuel Cocceji's theory of the law of nature and nations stimulated a number of controversies in the early eighteenth century. He was notably criticized by Leibniz, as well as by von Ludewig and Hertius, to whom he replied in the second dissertation of his Tractatus iuris gentium (1702). Because Samuel became famous as chief architect of Frederick II's law reforms, the theory of the law of nature and nations he had developed before he embarked on his political career has rarely been studied by contemporary

87 See Frank Grunert, 'The Reception of Hugo Grotius's De jure belli ac pacis in the early German enlightenment,' in Early Modern Natural Law Theories. Contexts and Strategies in the Early Enlightenment, ed. T.J. Hochstrasser and P. Schröder (Dordrecht, Boston, London: Kluwer, 2003), 92 and note 24.

88 Christoph Link, 'Menschenwürde und Gerechtigkeit als Staatszweck. Zum Werk Heinrich von Coccejis (1644-1719), in Die Ordnung der Freiheit. Festschrift für Christian Starck zum siebzigsten Geburtstag, ed. Rainer Grote et al. (Tübingen: Mohr Siebeck, 2007), 87-98. 
scholars. The only notable natural law scholar who showed real interest in the Coccejis' commentaries on Grotius was Adam Smith, and most of the research on the Coccejis' works on natural law has been undertaken to explain this. ${ }^{89}$ Regarding the law of nations, I attempted to show in section 3 of this chapter that Samuel's radical critique of the voluntary law of nations, which was first introduced by Grotius and marked a decisive turn in the history of the law of nations, further strengthened the 'naturalist' position of Pufendorf and his followers. The originality of Cocceji's fourth dissertation, which takes issue with the definition of the law of nations, rests on his hypothesis concerning the origin of the voluntary law of nations. As we have seen, he makes use of his expertise in Roman civil law in order to demonstrate that jus gentium proper does not rest on the nations' will. It was beyond the scope of this chapter to examine further aspects of the Coccejis' critique of De jure belli ac pacis. In the Swiss and indeed in the broader European context, it was the dualist account of the law of nations and the concept of the voluntary law in particular which became predominant in the second half of the eighteenth century, mainly through the influence of Emer de Vattel's Law of Nations.

\section{Bibliography}

Bisset, Sophie, 'Exploring the parameters of the école romande du droit naturel in the Journal helvétique: the case of Louis Bourguet's "Four letters on Leibniz", in Lectures du 'Journal helvétique', 1732-1782, ed. Séverine Huguenin and Timothée Léchot (Geneva: Slatkine, 2016), 315-328.

Bisset, Sophie, 'The reception of Pufendorf and Leibniz in the early école romande du droit naturel: Jean Barbeyrac and Louis Bourguet', Etudes Lumières.Lausanne, no. 7, février 2019, http://lumieres.unil.ch/fiches/biblio/9475/.

Borgeaud, Charles, Histoire de l'Université de Genève. L'Académie de Calvin, 1559-1798 (Geneva: Georg \& Cie., 1900).

Burlamaqui, Jean-Jacques, Principes du droit de la nature et de gens, ed. FortunéBarthélemy de Félice, 8 vols. (Yverdon: [de Félice], 1766-1768).

Burlamaqui, Jean-Jacques, Principles of Natural and Politic Law, transl. Thomas Nugent, ed. and with an introduction by Petter Korkman (Indianapolis, IN: Liberty Fund, 2006).

89 See Haakonssen, Natural Law and Moral Philosophy, 135-153; Metzger, 'Adam Smith's historical jurisprudence'. 
Clavel de Brenles, Abraham Daniel, De exemptione legatorum, a foro criminali ejus ad quem missi sunt (Marburg: Phil. Casim. Muller, 1740).

[Clavel de Brenles, A.D.], Eloge historique de Monsieur Charles Guillaume Loys de Bochat (Lausanne: Antoine Chapuis, 1755).

Cocceji, Henrici de, Grotius illustratus seu commentarii ad Hugonis Grotii de juri belli ac pacis libros III, ed. Samuel de Cocceji, 4 vols. (Wratislaviae: Johann Jacob Korn, $\left.1744-5^{2}\right)$.

Cocceji, Samuel, Tractatus Juris Gentium, de principio juris naturalis unico, vero, et adaequato (Frankfurrt an der Oder: Jeremiae Schreyi Haered. \& Joh. Christoph. Hartmann, 1702).

Corsini, Silvio, 'Vint-cinq ans d'édition et d'imprimerie à Lausanne au siècle des Lumières: le libraire Marc-Michel Bousquet, 1736-1761,' Revue historique vaudoise 120 (2012), 23-53.

Crucitti-Ullrich, Francesca Bianca, 'Bibliothèque italique (1728-1734),' in Dictionnaire des Journaux 160o-1789, accessed 2 February 2018, http://dictionnaire-journaux.gazettes18e.fr/journal/o165-bibliotheque-italique.

Grotius, Hugo, Le droit de la guerre et de la paix, transl. Jean Barbeyrac (Amsterdam: Pierre de Coup, 1724).

Grotius, Hugo, De jure belli ac pacis libri tres, 5 vols. (Lausanne: Marc-Michel Bousquet \& Cie., 1751-1752).

Grotius, Hugo, Recht des Krieges und des Friedens, transl. J.H. von Kirchmann (Berlin: L. Heimann, 1869).

Grotius, Hugo, De jure belli ac pacis libri tres, transl. of the ed. of 1646 by Francis W. Kelsey (The Classics of International Law, Oxford: Clarendon Press, 1925).

Grotius, Hugo, On the Law of War and Peace, ed. Stephen C. Neff (Cambridge: Cambridge University Press, 2012).

Grunert, Frank, 'The Reception of Hugo Grotius's De jure belli ac pacis in the early German enlightenment,' in Early Modern Natural Law Theories. Contexts and Strategies in the Early Enlightenment, ed. T.J. Hochstrasser and P. Schröder (Dordrecht, Boston, London: Kluwer, 2003).

Haakonssen, Knud, Natural Law and Moral Philosophy. From Grotius to the Scottish Enlightenment (Cambridge: Cambridge University Press, 1997).

Haggenmacher, Peter, 'Völkerrecht,' in Historisches Lexikon der Schweiz, accessed 2 January 2018, http://www.hls-dhs-dss.ch/textes/d/D9619.php.

Kadelbach, Stefan, 'Hugo Grotius: On the Conquest of Utopia by Systematic Reasoning', in System, Order, and International Law. The Early History of International Legal Thought from Machiavelli to Hegel, ed. Stefan Kadelbach, Thomas Kleinlein and David Roth-Isigkeit (Oxford: Oxford University Press, 2017), 134-159.

Link, Christoph, 'Menschenwürde und Gerechtigkeit als Staatszweck. Zum Werk Heinrich von Coccejis (1644-1719),' in Die Ordnung der Freiheit. Festschrift für Christian 
Starck zum siebzigsten Geburtstag, ed. Rainer Grote et al. (Tübingen: Mohr Siebeck, 2007), 87-98.

Loys de Bochat, Charles-Guillaume, Dissertatio inauguralis juridica de optimo principe (Basileae: typis Friderici Lüdij, 1717).

Loys de Bochat, Charles-Guillaume, Ouvrages pour et contre les services militaires étrangers, 3 vols. (Lausanne \& Genevae: Marc-Michel Bousquet \& Cie., 1738).

Metzger, Ernest, 'Adam Smith's historical jurisprudence and the "method of the civilians", in Smith in Glasgow 'og, 31 March-2 April 2009, Glasgow, UK, accessed 3 February 2018, http://eprints.gla.ac.uk/25492/.

Neff, Stephen C., Justice among Nations. A History of International Law (Cambridge, MA: Harvard University Press, 2014).

Peglow, Oliver, 'Cocceji, Heinrich von (1644-1719),' in The Dictionary of EighteenthCentury German Philosophers, ed. Heiner F. Klemme and Manfred Kuehn, vol. 1 (London: Continuum, 2010).

Peglow, Oliver, 'Cocceji, Samuel von (1679-1755),' in The Dictionary of EighteenthCentury German Philosophers, ed. Heiner F. Klemme and Manfred Kuehn, vol. 1 (London: Continuum, 2010).

Perrochon, Henry, 'Un savant d'autrefois: G.-Ch. Loys de Bochat (1695-1754),' Revue historique vaudoise 49 (1941): 29-33.

Philippe Meylan, Jean Barbeyrac (1674-1744) et les débuts de l'enseignement du droit dans l'ancienne Académie de Lausanne (Lausanne: F. Rouge \& Cie., 1937).

Poudret, Jean-François et al., L'enseignement du droit à l'Académie de Lausanne aux XVIII et XIXe siècles (Université de Lausanne, 1987).

Pufendorf, Samuel, Of the Law of Nature and Nations, transl. Basil Kennett, 4 th ed. (London: J. Walthoe, R. Wilkin, J. and J. Bonwicke, S. Birt, T. Ward and T. Osborne, 1729).

Rech, Walter, Enemies of Mankind. Vattel's Theory of Collective Security (Leiden, Boston: Martinus Nijhoff, 2013).

Schneider, Hans-Peter, 'Die wissenschaftlichen Beziehungen zwischen Leibniz und den beiden Cocceji (Heinrich und Samuel),' in Humanismus und Naturrecht in Berlin-Brandenburg-Preussen, ed. Hans Thieme (Berlin, New York: de Gruyter, 1979), 90-102.

Toyoda, Tetsuya, Theory and Politics of the Law of Nations. Political Bias in International Law Discourse of Seven Court Councilors in the Seventeenth and Eighteenth Centuries (Leiden, Boston: Martinus Nijhoff, 2011).

Vattel, Emer de, Le Droit des Gens, ou Principes de la Loi Naturelle, appliqués à la Conduite \& aux Affaires des Nations \& des Souverains (Londres, 1758).

Vattel, Emer de, The Law of Nations, ed. and with an Introduction by Béla Kapossy and Richard Whatmore (Indianapolis, IN: Liberty Fund, 2008).

Vitriarius, Philipp Reinhard, Institutiones juris naturae et gentium [...] ad methodum Hugonis Grotii (Lausanne: Antoine Chapuis, 1745). 
Wolff, Christian, Jus gentium methodo scientifica pertractatum, in quo jus gentium naturale ab eo, quod voluntarii, pactitii et consuetudinarii est, accurate distinguitur (Halle: Renger, 1749).

Zurbuchen, Simone, 'Bourguet, Louis (1678-1742),' in The Dictionary of EighteenthCentury German Philosophers, ed. Heiner F. Klemme and Manfred Kuehn, vol. 1 (London: Continuum, 2010), 135-137.

Zurbuchen, Simone, 'Théorie de la guerre juste et balance du pouvoir en Europe', in L'Europe en province: la Société du comte de la Lippe (1742-1747). Actes du colloque organisé à l'Université de Lausanne du 25 au 26 juin 2009, ed. Béla Kapossy et al. (Lausanne: Lumières.Lausanne, 2013): http://lumieres.unil.ch/fiches/biblio/5687/.

Zurbuchen, Simone, 'Emer de Vattel on the Society of Nations and the Political System of Europe,' in System, Order, and International Law, ed. Stefan Kadelbach, Thomas Kleinlein and David Roth-Isigkeit (Oxford: Oxford University Press, 2017), 263-282.

Zurbuchen, Simone, 'Teaching the Law of Nature and Nations in the Swiss Context', Etudes Lumières.Lausanne, no. 6, novembre 2018, http://lumieres.unil.ch/fiches/ biblio/9472/. 